\title{
An Inquiry into Ideological and Moral Construction of College Students as Network Virtual Group
}

\author{
Wang Zhijian \\ (1.The college of Economics and Management Shenyang Aerospace University Shenyang in \\ Liaoning 110136)
}

Keywords: College student; Network virtual group; Ideological and moral construction; Way

\begin{abstract}
With the rapid development of the network, the ideo-logical and moral construction of college students as network vir-tual group has gradually become a new content of moral educa-tion in colleges and universities. By analyzing the positive andnegative impact of the network on college students' ideologicaland moral construction, this paper explores the path of strength-ening ideological and moral construction of college students asthe network virtual group, so as to enhance the level of ideologicaland political education work.

With the rapid development of network information technology, the network has been widely popular among college students. As the contemporary college students whose thoughts are active, the speed of accepting new knowledge is the fastest,and the network has a profound impact on their Ideology, behavior, ethics and other aspects. This puts forward a serious challenge to the university students' ideological and moral education work. Therefore, analyzing the influence of network has on the ideological and moral construction of college students, seeking the way to solve problems, have become an urgent thing which promote the ideological and moral construction of college students.
\end{abstract}

\section{The network has a positive influence on the ideological and moral construction of college students' virtual group}

Network is a "double-edged sword", when the college students' management workers face the network,they must absorb its advantages and avoid its harmness, make full use of the advantage of network media, and play a positive role in university students' ideological and moral education. Though, contemporary college students' ideological and moral mainstream is positive, healthy and upward, but in the face of new situation, new condition and new challenges, university students' management workers must use a new network platform, grasp the ideology of college students timely, do well in the college students' self education and self management ability, and en sure the healthy and active development of the college students virtual group's ideological and moral construction。

The network provides a new platform for university student workers

With the advent of network information, the network has become an important medium for communication between people and people, especially for college students who accept new things quickly. However, the university students' world outlook, life outlook, values are not mature, in the face of a mass of the network information,they are not good at distinguishing the right and wrong, so the network will have an influence on the healthy growth of college students unavoidably. Therefore, it is urgent to strengthen the supervision of network information in colleges and universities, to complete the network education of college students, and to race to control the network consensus position of ideological and moral construction of university students. To this, in view of characteristics of the network information which have a large amount of information,wide coverage,strong autonomy,university student workers team should not only master the knowledge of ideological and moral construction of college students' network virtual groups, but also to grasp the network information technology. Only by combining the two things organically, can we effectively occupy the network education position, strengthen the ideological and moral construction of college students' network virtual groups, and improve the efficiency of students' work in colleges and universities. 


\section{It is helpful to grasp the ideological and moral dynamics of college students' network virtual groups in time}

Network's openness and information's sharing, not only provides a new way for college students virtual group to get online knowledge information , but also provides the university students' thoughts of communication and exchanges. Online information, especially on campus BBS, baidu post bar, QQ group, microblog, WeChat public platform have become the barometer of the ideological and moral dynamic of college students. For some personal mood, and even some hotspots and sensitive issues, college students are often willing to publish personal opinions and views on the Internet, discuss with each other and forward. College student management workers are aim for some negative information by means of grasping the student dynamic timely,guiding students actively enlightening and persuade education at the first time, college students management workers should minimize the negative effect timely, even kill it in the bud. At the same time, the college student management workers collect and analyse information by acquiring the network information students published,through the collection and analysis of information, induce student's thought tendency,so as to developing the specific strategy of students' education and management, to make sure the college students' network information platform is grasped in the hands of colleges and universities' managers. In this way, it not only grasps the true ideological and moral dynamics of college students, but also improves the pertinence of education's work.

It is helpful to cultivate the main consciousness of the virtual group of college students and the ability of self - education

Under the network environment,college students hunt and exchange information mainly by personal subjectivity, it changed the education mode dominated by teacher fundamentally, cultivated the university students' subject position in the education process. College students can not only choose different kinds of information through the Internet, but also satisfy their needs of various knowledge learning. In addition, many puzzles and problems can be solved through the Internet,enhance the ability of analyzing and handling problems. The independent participation network platform has a positive impact on cultivating college students' online virtual group's main body consciousness,improving university students' ability of self education, and promoting university students' ideological and moral construction .

\section{The network has a positive influence on the ideological and moral construction of college students' virtual group}

College students as builders and successors of the cause of socialist modernization, they must set up the correct world outlook, the life outlook and values, adhere to the leadership of the communist party of China, follow the road of socialism with Chinese characteristics unswervingly, to be a qualified socialist successors. Then, the complexity of the network environment for college students who have weak ability to tell right from wrong, it is easy to cause the negative impact of ideological and moral aspects, and even lead to the weakening of college students' mainstream ideology, indifference of moral ideas and sense of responsibility, some students will go to the network crime seriously. Throughout the network environment, the factors that have negative affect on college students' ideology and morality are multifaceted, which can be summed up in the following aspects mainly:

\section{The network causes the ideological and moral disorientation of university students}

At present, the us-led western countries, make full use of the leading advantage of network, they permeate "westernization" to China's political, economic, cultural and other fields ,and through penetration of ideology, to change the Chinese young generation's life outlook, world outlook and values. As college students who have active ideas, they are receptive to new things and lack judgment ability, it is easy to be affected by the subtle influence of the decadent western thought, such as hedonism and egoism. Thus, the political beliefs, moral standards and values of college students are becoming more and more westernized.

The network leads to the failure of ideological and ethical behavior of college students

In real life, every college student should restrain himself or herself according to social 
standards and moral norms, and must accept the supervision of public opinion. However, the openness, freedom and privacy of the Internet can enable college students to show their individuality and self-expression which are unrestrained. Because college students are short of self-discipline ability and the sense of right and wrong, on the one hand, they are free to express personal opinions and views, and they don't have to consider the words whether reasonable, and whether legitimate; On the other hand, they can easily become addicted to Internet violence and Internet pornography, even online crime. The collision of the constraints in real life and the "freedom" in the network environment will lead to the resistance of the real life's constraints inevitably, even confrontation. Thus, it is the misconduct of the ideological and moral behavior of college students.

\section{Network leads to the distortion of moral personality of college students}

The emergence of the Internet has made face-to-face communication change to a communication between people and computers. In real life, due to the lack of communication skills, many college students often are against the wall in direct contact with people, resulting in their lack of confidence of interpersonal relationships, and even fear. Therefore, many college students choose to avoid reality and choose to become addicted to the Internet. They are obsessed with online games, making friends and online love, and in the network, they need the comfort and confidence of the soul. This excessive self sealing of unreal world addiction could easily lead to adolescent psychological healthy growth of college students away from the real society, cause reality interpersonal emotion is becoming more and more weak, more lack of interpersonal skills, it is likely to make more and more students close self, selfish, indifference, paranoia, and even have extreme behavior, and they will not care the happiness of others in real life and social development, it is difficult to form a good moral personality of college students, and could eventually lead to the distortion of the moral personality.

\section{The path of strengthening ideological and moral construction of college students' network virtual group}

College students management workers only realize the positive influence and negative influence of network environment fully, can we truly do foster strengths and circumvent weaknesses, , thereby to give our best performance.On the basis of making full use of advantages that network environment brings to college students, overcoming the disadvantages, to promote the healthy development of college students' ideology and morality . To this, the university students' management workers should strengthen the network supervision and management, to improve the quality of the network ideological and moral construction team, to construct the ideological and moral quaternity construction mode of society, the media, schools, and integration.

\section{Raise the ideological and moral awareness of college students' network virtual group}

Strengthening ideological and moral construction of college students' online virtual group, the key is to help college students' network virtual community to identify the ideology and morality correctly, ensure that college students' online virtual group have correct view of the network from the thoughts. However, the correct understanding of the ideological morality of college students is not achieved overnight. It is a complicated systematic project that needs to be formed through the interaction between internal and external causes. Therefore, universities must make use of all education resources and rely on the power of various aspects to complete. In terms of education concept, universities should regard the marxist theory as a guide,regard patriotism education, socialism education, collectivism education as content, guide college students' online virtual group set up the correct world outlook, the outlook on life and values actively, to improve their ideological awareness, strengthen ideological and moral awareness; In the aspect of education main body, universities should adhere to marxist political theory teachers and administrative staff as the main body, other education workers as assist education personnel, realize the all-round, multi-level and multi-channel of virtual community college students' network moral education subject; In the way of education, we can make full use of the teaching of ideological and political theory in colleges and universities, and integrate the network ideological and moral education into the teaching, so as to 
ensure that all university students can receive the education of ideology and morality.Universities also can carry out a series of healthy and beneficial activities actively, through the activities to influence the college students' sentiment, purify the college students mind. In addition, colleges and universities should strive to create a good atmosphere of campus culture and provide a good education environment for the construction of ideological and moral education of college students.

\section{Strengthening the network monitoring and management of the ideological and moral education of university students}

The openness of the Internet provides a great opportunity for some immoral people, which leads to the pollution of network information, thus poses a serious challenge to the ideological and moral construction of college students. Therefore, colleges and universities should strengthen the concept of network legal system for college students and improve the online legal consciousness of college students. At the same time, in the domain of the immoral or even illegal behaviors of virtual community for college students thoughts, we should give them education or the legal punishment timely, so that college students can control and adjust the bad moral behavior consciously, prevent the occurrence of cyber crime. In addition, colleges and universities should set up relevant rules and regulations, put the network ideology and morality into the college students' comprehensive evaluation, regard them as a important basis of daily awards, selection, and joining the party, so that it can strengthen the self-discipline and self-management ability of network virtual community college students. In addition, colleges and universities also should use the advanced technology and equipment, use advanced technology to monitor the moral behavior of the college students' online virtual group closely, in view of the network bad information, we should have effective prevention and treatment, put an end to harmful information to enter the campus resolutely.

\section{Improve the quality of the team of network ideological and moral construction}

In order to strengthen the ideological and moral construction of online virtual groups of college students, we must have a good network ideological and moral construction team. To this, the network ideological and moral construction workers need to have good information consciousness and ability,so that they can take the essence and discard the dregs in a complex network environment, and obtain valuable information network, apply it to the ideological and moral education of the college students' online virtual group and management work. At the same time, the network ideological and moral construction workers need to have good ideology and morality, so that they will be able to obey laws and regulations of the network information, and to be the guidance and exemplary role of the construction of network moral education. In addition, the network ideological and moral construction workers need to have a good level of network technology, so that they are able to provide technical guidance and management in the campus network website construction, the college students' network moral education and the college students' ideological and moral network monitoring etc.

\section{Construct the ideological and moral construction mode of social, media, family and school}

In the age of network information, the ideological and moral construction of college students' network virtual groups cannot only rely on the efforts of the school, but also rely on society, media and family support. Only to build four integration mode of society, media,families, and schools, we can guarantee the ideological and moral construction of college students' online virtual group which is from all-round, multi-level and various aspects . To this, the society should inherit and carry forward the traditional Chinese virtues and form a good social atmosphere. The media should be "people-oriented", with political responsibility and moral responsibility as the starting point of propaganda, form the correct public opinion orientation; Families should respect and love each other, live in harmony, and create a harmonious family atmosphere. The school should adhere to the "students-oriented", strengthen the lessons education and moral education, promote the students' all-round development, and build the cradle of talent cultivation. Thus, social, media, family and school can give full play their advantages and form a resultant force on the ideological and moral construction of college students' network virtual group. 


\section{References}

[1] tan hao. The ideological and moral construction of college students in the Internet age [J]. China and foreign education research, 2011(1).

[2] ding jijun. A new study on the ideological morality of college students in the Internet era [J]. Journal of shanxi agricultural university, 2006(5).

[3] gao Ming. The present situation and countermeasures of network ideological and moral construction of university students [J]. Journal of jiangsu university, 2005(7).

[4] huang tingting. The way to strengthen the education of network ethics of college students in university $[\mathrm{J}]$.

[5] wang yongfeng.Study on the ideological and moral construction of college students in the Internet age [J]. Management of scientific research, 2009(5).

[6] zhao ying. Ideological and moral construction of college students in the Internet age [J]. University education science, 2004(4). 